\title{
Reduced Incidence of Bacterial Rot on Transgenic Insect-Resistant Maize in the Philippines
}

\author{
Samuel C. Dalmacio and Tomas R. Lugod, Pioneer Hi-Bred Philippines, 24/F, Antel Global Corporate Center, Or- \\ tigas Center, Pasig City, 1600 PH; Emmanuel M. Serrano, Pioneer Hi-Bred Philippines, Circumferential Rd., Purok \\ 4, Katangawan, General Santos, 9500 PH; and Gary P. Munkvold, Iowa State University, Dept. of Plant Pathology, \\ 160 Seed Science Center, Ames 50011
}

\begin{abstract}
Dalmacio, S. C., Lugod, T. R., Serrano, E. M., and Munkvold, G. P. 2007. Reduced incidence of bacterial rot on transgenic insect-resistant maize in the Philippines. Plant Dis. 91:346-351.

In the Philippines and parts of Southeast Asia, Asian corn borer (Ostrinia furnacalis) is a serious pest of maize, and injury from this insect often is associated with the occurrence of bacterial stalk and ear rot (caused by Erwinia chrysanthemi pv. zeae). The effect of transgenic insect protection on the incidence of bacterial stalk and ear rot was studied in the Philippines with seven field trials in Mindanao and two trials in Laguna. Three transgenic hybrids (expressing Bt protein $\mathrm{Cry} 1 \mathrm{Ab}$ ) and their conventional near-isogenic counterparts were included in Mindanao, and one transgenic/conventional hybrid pair was used in Laguna (Los Banos). In the Mindanao trials, bacterial stalk rot was rated on a 1 to 9 scale approximately 2 weeks before harvest, while in Laguna, bacterial rot mortality and bacterial ear rot incidence were assessed 10 days before and at harvest, respectively. In all trials, the number of Asian corn borer tunnels was assessed by splitting stalks at harvest. Results of the trials showed significant differences between the transgenic hybrids and their conventional counterparts in terms of bacterial stalk and ear rot incidence, number of Asian corn borer tunnels, and yield. Transgenic hybrids invariably showed significantly lower bacterial stalk rot mortality and ear rot incidence, no Asian corn borer infestation, and higher yield compared with their conventional counterparts. Average yield advantage of transgenic hybrids ranged from 1.2 to $5.1 \mathrm{t} / \mathrm{ha}$. Results confirm the important role of Asian corn borer in the initiation and spread of bacterial stalk and ear rot in maize; hence, the use of transgenic insect-resistant hybrids will have an added value in areas where this disease is prevalent.
\end{abstract}

Additional keywords: Bt corn

Asian corn borer (Ostrinia furnacalis) is a serious pest of maize in the Philippines and elsewhere in Asia and the Pacific islands. Closely related to the European corn borer (Ostrinia nubilalis), this insect has several overlapping generations in the Philippines, and the damage to maize is caused by larvae feeding on stalks, ears, and shanks (1). Yield losses of 4.8 to $30.9 \%$ were recorded (22), although losses of 20 to $80 \%$ have been reported in extension literature (13). An economic threshold of one larva per plant was established (16). Control recommendations include early planting, detasseling, the use of insecticides and biological control agents (including Bacillus thuringiensis), partial resis-

Corresponding author: Gary Munkvold

E-mail: munkvold@iastate.edu

Accepted for publication 29 September 2006.

doi:10.1094/PDIS-91-4-0346

(C) 2007 The American Phytopathological Society tance, and sanitation (1). The most common insecticidal active ingredient for Asian corn borer control in the Philippines is carbofuran. Concerns about the safety and environmental impacts of these products have motivated research on biological and transgenic control methods. Bt maize with transgenic protection against lepidopteran insects was first tested in the Philippines in 1996. Hybrids expressing the Cry1Ab protein (YieldGard event MON810, Monsanto Co., St. Louis, MO) are highly resistant to Asian corn borer $(7,10)$ and have been commercially available in the Philippines since 2003 (12).

Bacterial rot, caused by Erwinia chrysanthemi pv. zeae, was first reported in the Philippines in 1970 (3) and is now considered one of the most important maize diseases (15), particularly in low-elevation maize-growing areas in the Philippines during the wet season planting. It is also a major disease of maize in many other tropical and subtropical countries. Incidences of 80 to $85 \%$ have been reported in India (1). Infected plants may show any combination of the following symptoms: top rot, ear rot, root rot, and basal stalk rot (Fig. 1), invariably resulting in plant mortality, barren or rotten ears, or decreased grain weight. The pathogen survives in crop residue, is spread by splashing water and insects, and infects plants primarily through wounds. The role of insects in the initial outbreak and subsequent spread of bacterial rot has been demonstrated. In India, maize borer larvae (Chilo partellus) were shown to transmit the bacterium, resulting in stalk rot symptoms (23). In the Philippines, the involvement of Asian corn borer was demonstrated in an experiment where application of carbofuran reduced disease incidence and severity. The relationship was later confirmed in transmission experiments under screenhouse conditions (14). Control recommendations for bacterial rot diseases include chemical treatment of irrigation water, avoiding excess nitrogen fertilization, and genetic resistance. Applications of calcium hydroxide or streptomycin to the crop also have been effective (1). However, control of the disease is generally inadequate within its endemic range. With the recent introduction of Bt maize in the Philippines, primarily to control the Asian corn borer (Ostrinia furnacalis), it is hypothesized that the incidence of bacterial rot in areas prone to Asian corn borer infestation will be reduced through the use of $\mathrm{Bt}$ maize hybrids.

The purpose of this research was to compare the incidence of bacterial stalk and ear rot in Bt maize versus conventional maize under field conditions in different locations in the Philippines.

\section{MATERIALS AND METHODS}

Seven strip trials were conducted simultaneously from August 2003 to January 2004 in three Mindanao provinces: South Cotabato (1 location), Sultan Kuradat (3 locations), and North Cotabato (3 locations). Each trial was established in a different municipality. Two replicated field experiments were conducted at the Pioneer Hi-Bred Philippines, Inc., research center in Los Banos, Laguna, in separate but adjacent fields planted in July 2003 and 
June 2004. Weather during this period was typical of the region, with frequent rainfall during June $(\sim 265 \mathrm{~mm})$, July $(\sim 420 \mathrm{~mm})$, August $(\sim 486 \mathrm{~mm})$, September $(\sim 330$ $\mathrm{mm})$, October $(\sim 271 \mathrm{~mm})$, and November $(\sim 129 \mathrm{~mm})$, and drier conditions in December $(\sim 75 \mathrm{~mm})$ and January $(\sim 19 \mathrm{~mm})$. Temperatures also were typical of this region, ranging between 20 and $25^{\circ} \mathrm{C}$ during the night and between 30 and $35^{\circ} \mathrm{C}$ during the day. Moist conditions during the rainy season typically promote the development of bacterial rot diseases caused by Erwinia chrysanthemi pv. zeae. Plots were evaluated for the effect of Bt hybrids on naturally occurring incidence of bacterial stalk and ear rot. In the strip trials, three commercial Pioneer conventional maize hybrids (designated as hybrids $\mathrm{A}, \mathrm{B}$, and C) together with their respective nearisogenic $\mathrm{Bt}$ counterparts expressing Cry $1 \mathrm{Ab}$ (hybrids $\mathrm{BtA}, \mathrm{BtB}$, and $\mathrm{BtC}$ ) were grown in cooperating farmers' fields in 10 to 20 rows of variable lengths, spaced 60 to $70 \mathrm{~cm}$ apart. Each hybrid was planted in a single plot at each location. Plant populations varied from 40,000 to 60,000 plants/ha. Recommended cultural practices for hybrid maize production were applied throughout the growing season, including fertilizer application, which varied with the location based on soil fertility analysis. Land was prepared by plowing once followed by one pass with a field harrow. Manual weed control was performed. Bacterial stalk rot mortality was rated approximately 2 weeks before harvest on a 1 to 9 scale developed by Pioneer for internal use ( $1=71$ to $100 \%$ plants infected; 2 $=61$ to $70 \% ; 3=51$ to $60 \% ; 4=41$ to $50 \% ; 5=31$ to $40 \% ; 6=21$ to $30 \% ; 7=11$ to $20 \% ; 8=1$ to $10 \% ; 9=$ no infection). Disease assessments were conducted on all plants in the inner eight rows of the center $20 \mathrm{~m}$ of each plot. At harvest, 10 consecutive plants per plot were sampled from one of the inner rows for the number and length of Asian corn borer tunnels. Yields ( $t /$ ha) were calculated from grain weight of the eight inner rows and adjusted to $14 \%$ moisture. Data from each of the seven locations were considered a replicate and were subjected to two-way analysis of variance to assess differences between $\mathrm{Bt}$ and conventional hybrids in terms of yield, Asian corn borer tunneling, and bacterial stalk rot.

In Los Banos, two experiments were conducted using another commercial Pioneer hybrid (designated hybrid D) and its Bt counterpart (hybrid BtD). Land was prepared by plowing once followed by one pass with a field harrow. Manual weed control was performed. Plant populations were thinned by hand to 60,000 plants/ha (approximately $22 \mathrm{~cm}$ within-row spacing). In the first experiment, three replications of four-row plots, each measuring 5 $\mathrm{m}$ long and spaced $0.75 \mathrm{~m}$, were used following a randomized complete block de- sign. There were three treatments: hybrid $\mathrm{BtD}$, hybrid $\mathrm{D}+$ insecticide, and hybrid $\mathrm{D}$ without insecticide. Cypermethrin insecticide (Ammo 2.5 EC, Helena Chemical Co., Collierville, TN, USA) in a solution of $2 \mathrm{ml} /$ liter of water was applied on the appropriate plots about 45 days after planting. The insecticide was applied with a 16liter-capacity backpack sprayer, and each plot received approximately 0.5 liter of
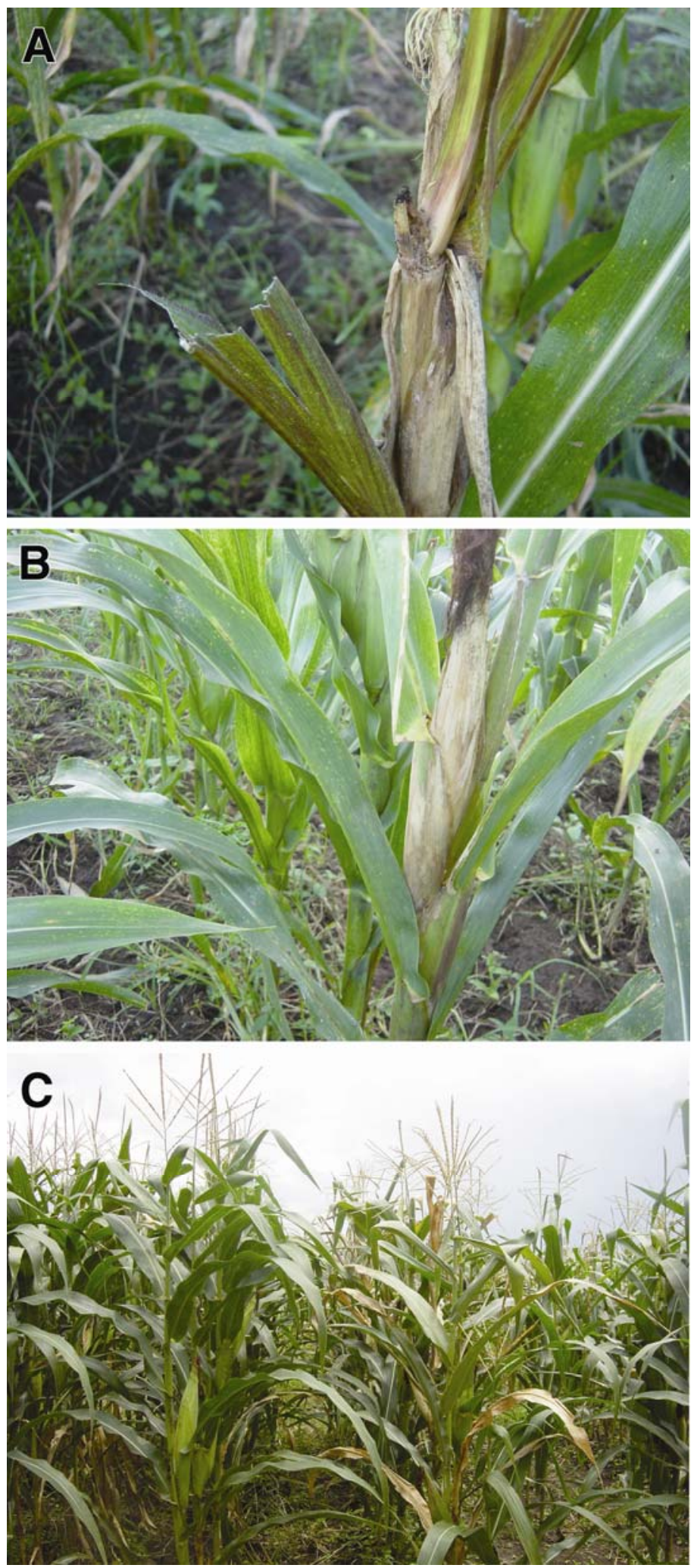

Fig. 1. Maize plants infected with Erwinia chrysanthemi pv. zeae, showing symptoms of stalk top-rot originating from a damaged ear (A), ear rot (B), and early symptoms of basal stalk rot (C, right). Pioneer hybrid $\mathrm{BtD}$ (left) and conventional hybrid D (right) are shown in the first experiment at Los Banos, Philippines (C). Conventional hybrid is showing early symptoms of bacterial stalk rot: poor vigor and premature senescence. 
solution, equivalent to a rate of $200 \mathrm{~g}$ a.i./ha. In the second experiment, the same plot dimensions and design were used with four replications and the following treatments: hybrid $\mathrm{D}$, hybrid $\mathrm{BtD}$, hybrid $\mathrm{D}+$ soil infestation with $E$. chrysanthemi pv. zeae, hybrid $\mathrm{BtD}+$ soil infestation with $E$. chrysanthemi pv. zeae, hybrid $\mathrm{D}+$ plant inoculation with $E$. chrysanthemi pv. zeae, and hybrid $\mathrm{BtD}+$ plant inoculation with $E$. chrysanthemi pv. zeae. Bacterial suspensions of a 12-h culture of E. chrysanthemi used for soil infestation about 40 days after planting and for plant inoculation near flowering time. The bacterial suspension was applied to the soil surface by backpack sprayer following a rain event at the rate of approximately 1 liter per plot. Plant inoculations were conducted by injecting $0.5 \mathrm{ml}$ of the suspension into the second internode above the soil line using a 300ml-capacity syringe inoculator. In both experiments, incidence of root and stalk pv. zeae $\left(1.0\right.$ to $\left.2.0 \times 10^{8} \mathrm{CFU} / \mathrm{ml}\right)$ were

rot from bacterial infection was recorded 10 days before harvest, while incidence of ear rot and number of tunnels from 10 sampled plants were taken at harvest time. Yields ( $t /$ ha) were calculated from the grain weight of the two inner rows and adjusted to $14 \%$ moisture. Data were analyzed by two-way ANOVA for the effects of treatment on yield, Asian corn borer tunneling, bacterial stalk rot, and bacterial ear rot. Data met assumptions for ANOVA without transformation. A proprietary statistical software package was used.

\section{RESULTS AND DISCUSSION}

In Mindanao (Table 1), bacterial stalk rot rating on the Bt hybrids ranged from 6 to 9 with an overall mean rating of 7.2 ; on the conventional hybrids the range was 3 to 6 with a mean of 4.9. No Asian corn borer tunneling was observed on the $\mathrm{Bt}$ hybrids in any of the locations, while the corresponding number of Asian corn borer tunnels on the conventional hybrids ranged

Table 1. Mean yield, Asian corn borer tunneling, and bacterial stalk rot scores for Pioneer Brand Bt and conventional maize hybrids in seven locations in Mindanao, Southern Philippines ${ }^{\mathrm{a}}$

\begin{tabular}{lcccc}
\hline Hybrid & $\begin{array}{c}\text { Yield } \\
(\mathbf{t} / \mathbf{h a})\end{array}$ & $\begin{array}{c}\text { Yield difference } \\
(\mathbf{\%})^{\mathbf{b}}\end{array}$ & $\begin{array}{c}\text { Asian corn borer } \\
\text { tunneling (no.) }\end{array}$ & $\begin{array}{c}\text { Bacterial stalk } \\
\text { rot (1-9 scale) }\end{array}$ \\
\hline Hybrid BtA (Bt) & 5.13 & 27.9 & 0.0 & 7.1 \\
Hybrid A & 4.01 & & 3.7 & 4.7 \\
Hybrid BtB (Bt) & 5.26 & 28.6 & 0.0 & 7.4 \\
Hybrid B & 4.09 & & 5.1 & 5.0 \\
Hybrid BtC (Bt) & 5.44 & 31.7 & 0.0 & 7.0 \\
Hybrid C & 4.13 & & 4.4 & 5.0 \\
Mean - Bt & 5.28 & 29.4 & 0.0 & 7.2 \\
Mean - conventional & 4.07 & & 4.4 & 4.9 \\
CV & $10.5 \%$ & & $69.6 \%$ & $10.5 \%$ \\
LSD (0.05) & 0.52 & & 1.8 & 0.7 \\
\hline
\end{tabular}

${ }^{a}$ Based on single replicate plots of each hybrid per location; each location considered a replication.

b $100 \times$ (yield of Bt hybrid - yield of conventional hybrid) / yield of conventional hybrid. from 1.7 to 9.3 tunnels per plant for an overall mean of 4.4 tunnels. Yield of the $\mathrm{Bt}$ hybrids ranged from 3.16 to 8.54 t/ha with an overall mean of $5.28 \mathrm{t} / \mathrm{ha}$, whereas those of the conventional hybrids ranged from 1.92 to $7.15 \mathrm{t} / \mathrm{ha}$ and an overall mean of $4.07 \mathrm{t} / \mathrm{ha}$. Mean yield advantages of the $\mathrm{Bt}$ hybrids hybrid BtA, hybrid BtB, and hybrid $\mathrm{BtC}$ over their conventional counterparts were $1.12 \mathrm{t} / \mathrm{ha}(27.9 \%), 1.17 \mathrm{t} / \mathrm{ha}$ $(28.6 \%)$, and 1.31 t/ha $(31.7 \%)$, respectively, or an overall mean yield advantage of $1.21 \mathrm{t} / \mathrm{ha}(29.4 \%)$. Southern rust (Puccinia polysora Underw.) and Diplodia leaf blight and ear rot (Stenocarpella macrospora (Earle) Sutton) were common in several locations at low severity that did not impact yield; incidence of these diseases did not differ between Bt and conventional hybrids.

In the first Los Banos experiment (Table 2), hybrid BtD was significantly different from its conventional counterpart (with or without insecticide treatment) in terms of number of Asian corn borer tunnels, percent plants showing root and stalk rot symptoms (Fig. 1), and percentage of ears showing ear rot symptoms (Fig. 2). No Asian corn borer tunneling was observed on hybrid $\mathrm{BtD}$, whereas hybrid $\mathrm{D}+\mathrm{Ammo}$ and hybrid D showed 4.5 and 3.8 tunnels per plant, respectively. The significant differences between hybrid BtD and hybrid $D$ were reflected in significant yield differences (Table 2). Yield of hybrid BtD was $6.86 \mathrm{t} / \mathrm{ha}$, while yields of hybrid D+Ammo and hybrid $\mathrm{D}$ were 2.61 and $1.75 \mathrm{t} / \mathrm{ha}$, respectively, a remarkable yield advantage of as much as $5.11 \mathrm{t} / \mathrm{ha}(292 \%)$ in favor of hybrid BtD over the untreated plots. Insecticide treatment did not provide effective control of Asian corn borer, although it
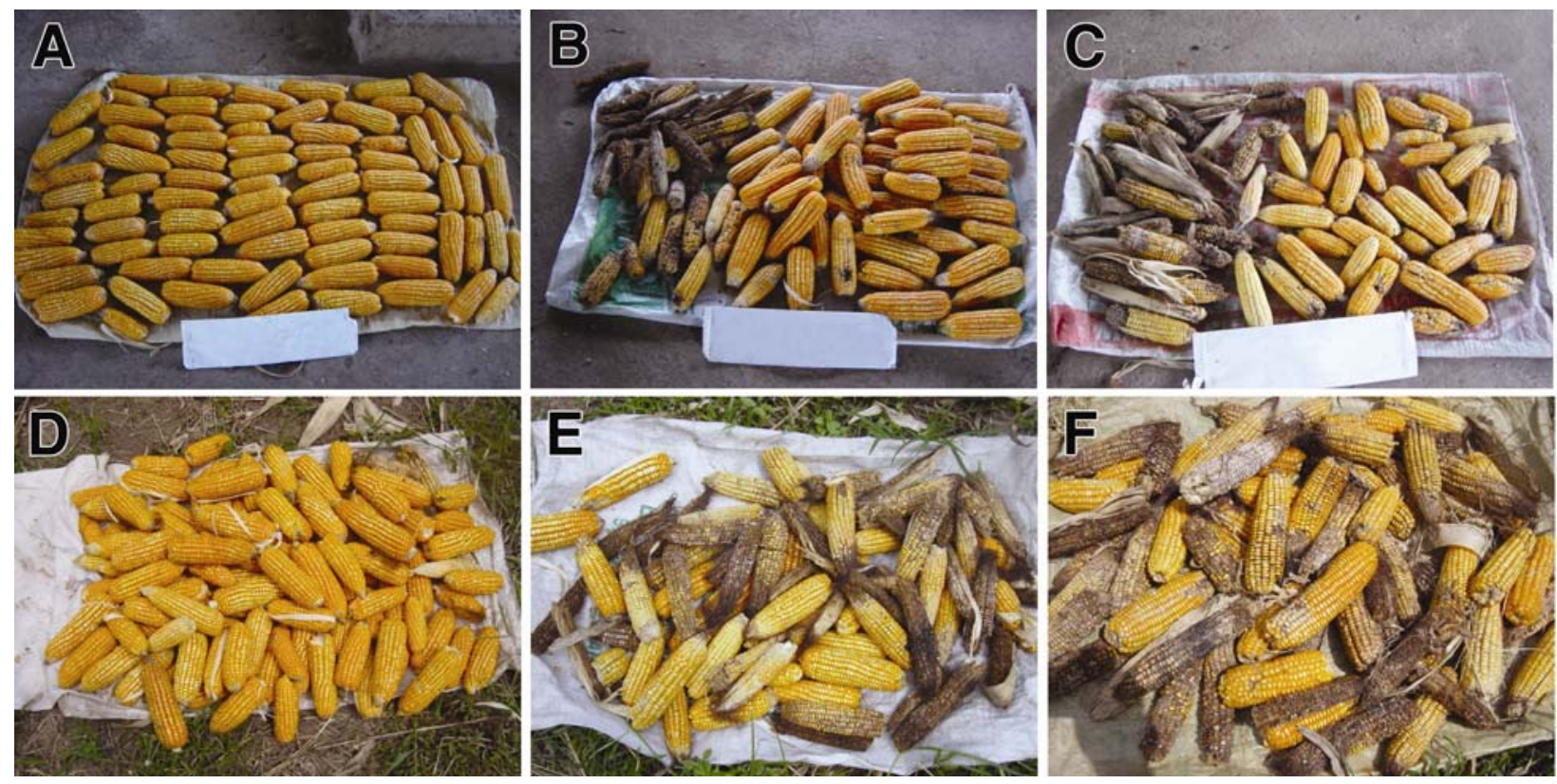

Fig. 2. Newly harvested ears of Pioneer hybrids BtD (A and D), conventional hybrid D treated with Ammo insecticide (B and E), and nontreated conventional hybrid D (C and F), showing varying levels of bacterial ear rot incidence in the first (A-C) and second (D-F) reps of the first experiment conducted at Los Banos. 
showed significant yield advantage over the untreated plots.

In the second Los Banos experiment, there were also significant differences between hybrid $\mathrm{BtD}$ and its conventional counterpart (Fig. 3), despite a minimal incidence of Asian corn borer infestation. Soil infestation or plant inoculation with $E$. chrysanthemi pv. zeae did not affect the results. No Asian corn borer infestation was observed on hybrid $\mathrm{BtD}$, while hybrid D showed an average of 1.9 tunnels per plant. Percentages of plants showing bacterial root and stalk rot symptoms and ear rot symptoms were significantly lower for hybrid $\mathrm{BtD}$ than for hybrid $\mathrm{D}$. Overall mean yields of hybrid $\mathrm{BtD}$ and hybrid $\mathrm{D}$ were 5.66 and $3.57 \mathrm{t} / \mathrm{ha}$, a yield difference of $2.03 \mathrm{t} / \mathrm{ha}$ or $56.9 \%$ yield advantage in favor of hybrid BtD.

Incidence of the root rot phase of bacterial rot infection in $\mathrm{Bt}$ maize and its non-Bt counterpart did not differ (data not shown), which is expected because Asian corn borer infestation is confined to the upper parts of the plant.

The large yield reduction observed in the two experiments conducted in Los Banos can be attributed primarily to the extensive damage caused by E. chrysanthemi pv. zeae. Plants infected through the roots and stalks usually die prematurely, resulting in barren plants or poorly filled ears, while ear infection usually results in complete yield loss from direct destruction of the grain (Fig. 3). The level of Asian corn borer infestation in the two experiments is considered light to moderate; based on regulatory trials conducted by Pioneer in the Philippines (2), yield advantage of $\mathrm{Bt}$ maize over its conventional counterpart due to Asian corn borer control alone does not usually exceed $15 \%$.

Laysa (14) presented conclusive results that insects play a role in the initial outbreak and spread of bacterial stalk rot. Carbofuran applied at planting time and at 1 and 2 months after planting significantly reduced incidence of bacterial stalk rot compared with plots where no carbofuran was applied. In unprotected plants, stalk rot often occurred following Asian corn borer attack. It was demonstrated in subsequent experiments that wounds were necessary for bacterial rot infection and apparently served as primary sites for entry of the bacterium. Inoculation of the roots, stalks, young ears, and whorls by drenching with a bacterial suspension only resulted in infection when plants were injured prior to inoculation. Thind and Singh (23) also reported that maize borer acts as a carrier of E. chrysanthemi pv. zeae.

The results presented in this paper provide confirmation of the role played by insects, particularly Asian corn borer, in the development of bacterial stalk and ear rot of maize. Insects also act as vectors of other stalk and ear rot diseases of maize, such as European corn borer larvae and
Fusarium species (21), corn earworm or southwestern corn borer, and Fusarium or Aspergillus spp. (5). Insects may also predispose maize plants to infection by creating wounds that serve as entry points for pathogens. Many pathogens, particularly bacterial pathogens, require wounds to gain entry into the plant tissues, and many lepidopteran insects provide this requirement. Even when the larvae do not directly carry the fungi into the stalks, spores subsequently deposited on the wounded tissue are very likely to infect the plant (18). Furthermore, insect injury to the leaves, roots, and stalks creates stress that predisposes the plants to root and stalk rot development.

This paper also adds to the evidence of secondary benefits of $\mathrm{Bt}$ transgenic maize through reductions in incidence or severity of certain maize diseases associated with insect injury. A number of researchers have demonstrated reductions in fungal ear rot diseases and their associated mycotoxins through the use of Bt maize (17). In the United States, experiments have been conducted comparing disease and mycotoxin levels between Bt hybrids and "nearisogenic" conventional hybrids. Results of these studies have consistently demonstrated that hybrids with transgenic protection against lepidopteran pests have significantly lower incidence and severity of Fusarium ear rot and produce grain with lower fumonisin concentrations than their non-Bt counterparts (18). Similar results have been obtained in studies conducted in Iowa, Illinois, Indiana, Kentucky, Pennsyl-
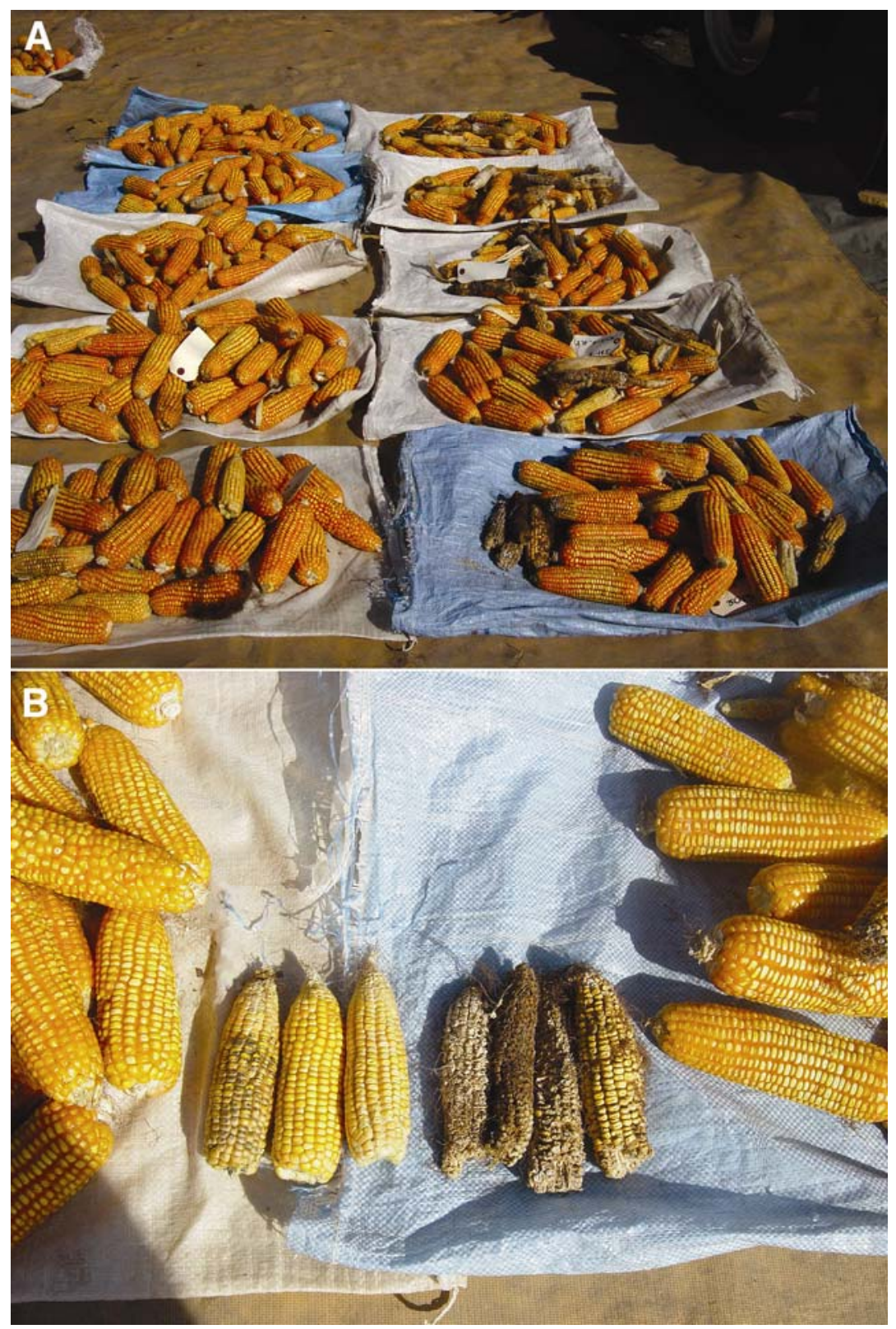

Fig. 3. A, harvested ears from hybrid $B t D(L)$ and hybrid $D(R)$ showing differential incidence of bacterial ear rot in the second trial at Los Banos; $\mathbf{B}$, maize ears showing effects of bacterial rot infection on the roots or stalk (center left) and ears (center right), compared to ears from healthy plants (far left and far right). 
Table 2. Mean yield, Asian corn borer tunneling, and bacterial stalk rot and ear rot incidences for Pioneer Brand Bt and conventional maize hybrids in two experiments at Los Banos, Luzon Province, Philippines ${ }^{\mathrm{a}}$

\begin{tabular}{|c|c|c|c|c|c|}
\hline Experiment & Treatment & $\begin{array}{l}\text { Yield } \\
(\mathrm{t} / \mathrm{ha})\end{array}$ & $\begin{array}{c}\text { Asian corn borer } \\
\text { tunneling (no.) }\end{array}$ & $\begin{array}{l}\text { Bacterial stalk rot } \\
\text { incidence }(\%)\end{array}$ & $\begin{array}{c}\text { Bacterial ear rot } \\
\text { incidence }(\%)\end{array}$ \\
\hline 1 & $\begin{array}{l}\text { Hybrid BtD }(\mathrm{Bt}) \\
\text { Hybrid D+Ammo } \\
\text { Hybrid D } \\
\text { CV } \\
\text { LSD }(0.05)\end{array}$ & $\begin{array}{c}6.86 \\
2.61 \\
1.75 \\
20.9 \% \\
1.3\end{array}$ & $\begin{array}{l}0.0 \\
4.5 \\
3.8 \\
44.3 \% \\
2.0\end{array}$ & $\begin{array}{l}22.4 \\
63.2 \\
68.7 \\
21.7 \% \\
17.2\end{array}$ & $\begin{array}{l}\quad 6.2 \\
56.3 \\
52.7 \\
29.6 \% \\
29.8\end{array}$ \\
\hline 2 & $\begin{array}{l}\text { Hybrid BtD } \\
\text { Hybrid D } \\
\text { Hybrid BtD+RT } \\
\text { Hybrid D+RT } \\
\text { Hybrid BtD+PLT } \\
\text { Hybrid D+PLT }\end{array}$ & $\begin{array}{l}5.99 \\
3.66 \\
4.99 \\
3.95 \\
6.01 \\
3.09\end{array}$ & $\begin{array}{l}0.0 \\
2.0 \\
0.0 \\
1.5 \\
0.0 \\
2.2\end{array}$ & $\begin{array}{l}16.3 \\
48.0 \\
19.8 \\
42.9 \\
16.0 \\
50.2\end{array}$ & $\begin{array}{r}8.7 \\
37.5 \\
17.4 \\
37.6 \\
10.2 \\
46.6\end{array}$ \\
\hline & $\begin{array}{l}\text { Mean (Hybrid BtD) } \\
\text { Mean (Hybrid D) }\end{array}$ & $\begin{array}{l}5.66 \\
3.57\end{array}$ & $\begin{array}{l}0.0 \\
1.9\end{array}$ & $\begin{array}{l}17.4 \\
47.0\end{array}$ & $\begin{array}{l}12.1 \\
40.6\end{array}$ \\
\hline & $\begin{array}{l}\text { CV } \\
\text { LSD (0.05) }\end{array}$ & $\begin{array}{c}13.3 \% \\
0.84\end{array}$ & $\begin{array}{c}68.5 \% \\
0.9\end{array}$ & $\begin{array}{l}16.1 \% \\
15.4\end{array}$ & $\begin{array}{l}12.8 \% \\
13.3\end{array}$ \\
\hline
\end{tabular}

a Data are based on three replicate plots (experiment 1) and four replicate plots (experiment 2), four rows by $5 \mathrm{~m}$ long. Yield was measured on the middle two rows of each plot. Insect injury and disease were assessed on 10 plants per plot.

b Ammo 2.5 EC, Helena Chemical Co., Collierville, TN, USA (Cypermethrin), applied at $200 \mathrm{~g}$ a.i./ha by backpack sprayer.

${ }^{\mathrm{c}} \mathrm{RT}=$ root inoculation with Erwinia chrysanthemi pv. zeae $;$ PLT = stalk inoculation with Erwinia chrysanthemi pv. zeae .

vania, Georgia, Kansas, Alabama, Missouri, Tennessee, Nebraska, and North Carolina in the United States, and in Italy, Spain, France, Germany, and Argentina $(4,6,9,11,19,20)$. Some field studies also have shown reduced kernel infection by Aspergillus flavus and lower aflatoxin concentrations in Bt hybrids compared with their non-Bt counterparts (24). However, these reductions have been less dramatic and less consistent than those seen for fumonisins (18). Under some conditions, stalk rot symptoms caused by fungal pathogens also were reduced in Bt hybrids compared with their conventional counterparts (8). In the Philippines, the incidence of Fusarium ear rot and charcoal stalk rot was very much reduced in hybrid BtD compared with its conventional hybrid and other conventional hybrids (2). In one regulatory field trial in Luzon where very severe infestation by Asian corn borer was observed, hybrid $\mathrm{BtD}(\mathrm{Bt})$ showed only $2.7 \%$ Fusarium ear rot, while the rest of the conventional hybrids, hybrid D, 30D44, 30P60, and C818, showed 27.8, $31,33.7$, and $45.2 \%$ incidence, respectively. In the same trial, hybrid BtD showed $21.8 \%$ charcoal stalk rot, while hybrid D showed $81.8 \%$, and three other conventional hybrids showed 84.1, 65.7, and $73 \%$, respectively (2). However, no difference in charcoal stalk rot incidence was observed in a postregulatory trial where Asian corn borer infestation was moderate (2); and in another study in the Philippines (4), fumonisin levels were similarly low in both $\mathrm{Bt}$ and conventional maize hybrids. These results suggest that stress due to insect damage must be high to predispose maize plants to charcoal rot infection and to promote high fumonisin levels in the Philippines.

In the Philippines, Bt maize was commercialized in December 2002 and is now planted on more than 50,000 hectares.
Considering the importance of bacterial stalk and ear rot in certain maize growing areas of the country (and other tropical maize growing areas), expanded use of the $\mathrm{Bt}$ maize and introduction of other $\mathrm{Bt}$ maize events in those areas where Asian corn borer infestation and bacterial rot incidence are common will provide an added value by reducing damage caused by the disease.

\section{ACKNOWLEDGMENTS}

We are grateful to Vinjo Manero, Pioneer Philippines, for his assistance in gathering the data from the field experiments, and to Heather Erickson, Pioneer Hi-Bred, Int., for assistance in preparing the figures.

\section{LITERATURE CITED}

1. CAB International. 2005. Crop Protection Compendium, 2005 ed. CAB International, Oxfordshire, UK.

2. Dalmacio, S. C. 2003. Multi-location field trials of Bt transgenic Bt corn hybrids against Asiatic corn borer, Ostrinia furnacalis Guenee, in the Philippines. Terminal Report, National Committee on Biosafety of the Philippines.

3. Dalmacio, S. C., and Exconde, O. R. 1970. Disease of corn unreported in the Philippines. Philipp. Phytopathol. 6:89-97.

4. de la Campa, R., Hooker, D. C., Miller, J. D., Schaafsma, A. W., and Hammond, B. G. 2005. Modeling effects of environment, insect damage, and Bt genotypes on fumonisin accumulation in maize in Argentina and the Philippines. Mycopathologia 159:539-552.

5. Dowd, P. F. 1998. Involvement of arthropods in the establishment of mycotoxicogenic fungi under field conditions. Pages 307-350 in: Mycotoxins in Agriculture and Food Safety. K. K. Sinha and D. Bhatagnar, eds. Marcel Dekker, New York.

6. Dowd, P. F., and Munkvold, G. P. 1999. Associations between insect damage and fumonisin derived from field-based insect control strategies. Proc. 40th Annu. Corn Dry Milling Conf., June 3-4, 1999. Peoria, IL.

7. Fernandez, E. C., and Legacion, D. M. 1997. Progress of host plant resistance research to the Asiatic corn borer in the Philippines. Insect resistant maize: Recent advances and utilization. Pages 293-296 in: Proc. Int. Sympos., In- ternational Maize and Wheat Improvement Center, 27 November-3 December 1994.

8. Gatch, E. W., Hellmich, R. L., and Munkvold, G. P. 2002. A comparison of maize stalk rot occurrence in Bt and non-Bt hybrids. Plant Dis. 86:1149-1155.

9. Hammond, B. G., Campbell, K. W., Pilcher, C. D., Degooyer, T. A., Robinson, A. E., McMillen, B. L., Spangler, S. M., Riordan, S. G. Rice, L. G., and Richard, J. L. 2004. Lower fumonisin mycotoxin levels in the grain of $\mathrm{Bt}$ corn grown in the United States in 2000-2002. J. Agric. Food Chem. 52:1390-1397.

10. He, K., Wang, Z., Zhou, D., Wen, L., Song, Y., and Yao, Z. 2003. Evaluation of transgenic Bt corn for resistance to the Asian corn borer (Lepidoptera: Pyralidae). J. Econ. Entomol. 96:935-940.

11. ILSI Health and Environmental Sciences Institute. 1999. An evaluation of insect resistance management in Bt field corn: A science-based framework for risk assessment and risk management. ILSI Press, Washington, DC.

12. James, C. 2005. Global status of commercialized biotech/GM crops: 2005. ISAAA Brief No. 34. ISAAA, Ithaca, NY.

13. Javier, P. A., Agsaoay, M. V., and de la Cruz, J. L. 2004. Influence of YieldGard on the effectiveness of Trichogramma evanescens (Hymenoptera: Trichogrammatidae), an egg parasitoid of Asian corn borer, Ostrinia furnacalis Guenee. Terminal Report, NCPC, UPLB.

14. Laysa, Fe. D. 1980. Etiology and epidemiology of bacterial stalk rot of corn. Ph.D. diss. U.P. at Los Banos, College, Laguna, Philippines.

15. Lugod, T. R., and Dalmacio, S. C. 1998. Corn pests and diseases manual. 56+VII p. Pioneer Hi-Bred Philippines, Inc.

16. Morallo-Rejesus, B., Buctuanon, E. M., and Rejesus, R. S. 1990. Defining the economic threshold determinants for the Asian corn borer, Ostrinia furnacalis (Guenee) in the Philippines. Trop. Pest Manag. 36:114-121.

17. Munkvold, G. P. 2003. Cultural and genetic approaches to managing mycotoxins in maize. Annu. Rev. Phytopathol. 41:99-116.

18. Munkvold, G. P., and Hellmich, R. L. 2000 Genetically modified, insect resistant maize: Implications for management of ear and stalk diseases. Online. Plant Health Progress doi:10.1094/PHP-2000-0912-01-RV.

19. Munkvold, G. P., Hellmich, R. L., and Rice, L. 
G. 1999. Comparison of fumonisin concentrations in kernels of transgenic Bt maize hybrids and nontransgenic hybrids. Plant Dis. 83:130138.

20. Munkvold, G. P., Hellmich, R. L., and Showers, W. B. 1997. Reduced Fusarium ear rot and symptomless infection in kernels of maize genetically engineered for European corn borer resistance. Phytopathology 87:1071-1077.
21. Sobek, E. A., and Munkvold, G. P. 1999. European corn borer (Lepidoptera: Pyralidae larvae as vectors of Fusarium moniliforme, causing kernel rot and symptomless infection of maize kernels. J. Econ. Entomol. 93:503509.

22. Teng, P. S., Fernandez, P. G., and Hofer, J. 1992. Pest and loss assessment on field corn in three Philippine islands. Pages 199-205 in: Proc. 3rd Int. Conf. Plant Prot. Tropics, Genting High- lands, Malaysia, 20-23 March 1990.

23. Thind, B. S., and Singh, N. 1975. Maize bore (Chilo partellus) as carrier of Erwinia carotovora var. zeae, the causal agent of bacterial stalk rot of maize. Curr. Sci. 45:117-118.

24. Williams, W. P., Windham, G. L., Buckley, P. M., and Perkins, J. M. 2005. Southwestern corn borer damage and aflatoxin accumulation in conventional and transgenic corn hybrids. Field Crops Res. 91:329-336.

\section{ERRATUM}

This article was corrected on March 27, 2007. In the caption for Figure 3, the labels L and R were changed in order to identify the hybrids correctly. 